\title{
New Inspection Technologies for Identification of Failure in the Materials and Welded Joints for Area of Gas Industry
}

Peter Vrzgula, Martin Faturík, Miloš Mičian

Faculty of Mechanical Engineering, University of Žilina. Univerzitná 1, 01026 Žilina. Slovak Republic. E-mail: peter.vrzgula@hotmail.com, milos.mician@fstroj.uniza.sk.

Contribution presents new principles of inspection technology for examination of integrity of the gas pipelines material and its welded joints. Information is linked with real output from measuring on gas pipelines and results are compared to conventional NDT methods. Visual control is done as a first non-destructive test in $100 \%$ extent for all welds. It must be executed well in advance before all the other tests in order to remove superficial defects and irregularities, which could prevent correct application and evaluation of other tests. It is used to detect superficial defects and geometrical irregularities, especially cracks on the surface of weld or in the heat affected area, elevation of weld, undercuts in transitions to base material, defects in the root of weld, if it is accessible from pipe's inner side, including inadmissible offset of weld surfaces from pipe's outer side and their continuity of transition to the weld. The following are the tests to detect internal defects radiographically, respectively by an ultrasound and tests to detect superficial cracks for branches, necks and fillet welds.

Keywords: Gas industry, NDT, Phased Array, OmniScan

\section{Acknowledgments}

This work has been supported by Scientific Grant Agency of Ministry of Education of the Slovak republic, grant VEGA: V-11-015-00 and non-profit organization EkoFond project No. 561/PG04/2011.

\section{References}

[1] KOVÁČIK, M. - HYŽA, R. (2013). Ultrazvuková skúška časti obvodového zvaru čpavkovej tlakovej nádoby technikami Phased Array a TOFD. [Online] 2013. [Dátum: 21. 04 2013.] http://www.ssndt.sk/files/odborne/PA\%20a\%20TOFD\%20na\%20cpavku.pdf.

[2] KOVÁČIK, M. (2010). Skúšanie materiálov ultrazvukom. Bratislava : s.n., 2010.

[3] LANGENBERG, K. J., MARKLEIN, R., MAYER, K. (2012). Ultrasonic nondestructive testing of materials (Theoretical foundations). Boca Raton : CRC Press, 2012. s. 736. ISBN 978-1-4398-5588-1.

[4] LIETNER, B. (2003). Nedeštruktívne skúšanie materiálov v plynárenstve. Žilina : Žilinská univerzita v Žiline, 2003. s. 197. ISBN 80-8070164-4.

[5] MARTANČÍK, B. (2012). Výskum diagnostiky defektov pomocou nových ultrazvukových metód TOFD a Phased Array a vplyv na životnost’ zváraných konštrukcií. Bratislava : Slovenská technická unverzita v Bratislave, 2012. s. 151, dizertačná práca.

[6] OBRAZ, J. (1989). Zkoušení materiálu ultrazvukem. Praha : SNTL Nakladatelství technické literatury, 1989. s. 464. ISBN 80-03-00097-1.

[7] OLYMPUS. (2004). Introduction to Phased Array Ultrasonic Technology Applications. Waltham, MA : Olympus NDT, 2004. s. 351. ISBN 0-9735933-0-X.

[8] OLYMPUS. (2012). Phased Array Testing Basic Theory for Industrial Applications. 2nd ed. Waltham, MA : Olympus NDT, 2012. s. 113. DMTA-20003-01EN.

[9] MEŠKO, J., FABIÁN, P., HOPKO, A., KOŇÁR, R. (2011). Shape of heat source in simulation program SYSWELD using different types of gases and welding methods. In: Strojírenská technologie: časopis pro vědu, výzkum a výrobu. s. 6-11. Edition 16. Issue 5. ISSN 1211-4162. 